\title{
İSLÂM VE OSMANLI HUKUKU'NDA KASAME MÜESSESESİ
}

\author{
Dr. Aybars PAMIR*
}

\section{GíRIŞ}

Makalemizle, "Ukubat" adıyla da bilinen İslâm Ceza Hukuku'nun bir müessesesi olan ve "Cezaların Şahsîliği”" ilkesinin istisnasını teşkil eden "Kasame"nin ayrıntılı bir biçimde incelenmesi amaçlanmıştır.

"Kasame" bugün modern hukuk sistemlerinde uygulaması olmayan, ancak geçmişte yaşamış çeşitli toplumlarda kabul edilmiş bir müessesedir. Bu cümleden de anlaşılacağ üzere Kasame sadece İslâm Hukuku'na özgü bir müessese değildir; eski Yunan'da, Yahudi toplumunda, Cahiliye Çağ 1 Arapları'nda, hatta Ortaçağ İngilteresi'nde bile uygulama alanı bulmuştur'. Bu durum, değişik hukuk müesseseleri gibi Kasame'nin de eski toplumların günlük yaşantılarından kaynaklanan bir ihtiyaçtan doğduğunu ve tarih içinde çeşitli toplumların hukuksal açıdan birbirlerinden etkilenerek bazı kurum ve kuralları aldıklarını bizlere kanıtlar.

Kasame sadece tarihte kalmış bir müessese olarak algılanmamalıdır; aynı zamanda Kasame'nin diğer pek çok hukuk kurumu gibi Ceza Hukuku'nun modernleşme sürecinde basamak teşkil eden bir uygulama olduğu da unutulmamalıdır.

\section{GENEL OLARAK}

İslâm Ceza Hukuku'nda "Diyet" uygulamasından çıkan ilginç bir hukuk kurumu dikkat çekmektedir: "KASAME". Kasame bir köy ya da mahallede, yol veya cami gibi umumî bir yerde, yahut özel bir mülk içinde üzerinde katil belirtileri mevcut olan katili meçhul bir ceset bulunması durumunda, maktul ya da maktulenin yakınlarının dava etmeleri üzerine söz

Ankara Üniversitesi Hukuk Fakültesi, Hukuk Tarihi Anabilim Dalı Araştırma Görevlisi.

Ansay, Sabri Şakir: Hukuk Tarihinde İslâm Hukuku, Ankara, 1958, s. 287 - Cin, HalilAkyılmaz, Gül: Türk Hukuk Tarihi, Konya, 2003, s. 217 vd. 
konusu yerin halkından elli kişiye "vallahi biz onu öldürmedik, katilini de bilmiyoruz" şeklinde yemin ettirilmesi esasına dayanır. Yeminin edilmesiyle birlikte öldürülen kişinin diyeti, cesedin bulunduğu yer bir özel mülk ise mülk sahibinin akilesine, umumî bir yer ise köy veya mahalle halkına ödettirilir².

Görüldügü gibi, "o kişiyi ben öldürmedim ve öldüreni de bilmiyorum" şeklindeki yemin, o yer ahalisinin suçu işlediğine bir karine sayılmaktadır; çünkü onlar böyle bir olayı önleyememekle ve katili görmemekle halkın huzurunu kaçırmışlardır. Bu nedenle öldürülenin diyeti onlardan alınacaktır ${ }^{3}$.

Kasame müessesesi Osmanlı kanunnamelerinde şöyle formüle edilmiştir: "Eğer mahalle içinde veya köy arasında maktul bulunsa, elbette teftiş edüp katili bulduralar veyahut diyet çektireler. Ve eser-i katl bulunmazsa, mücerret meyyit bulunmağla incitmeyeler" ${ }^{\text {" }}$. Bu ifadeden de anlaşılabildiği gibi Kasame, bazı açılardan saf İslâm devleti sayılmasa da Osmanlı Devleti'nin hukuk uygulamasında yer almış, bu konu Ukubat'ın temel konularından biri olarak yüzyıllarca yaşamıştır.

Kasame uygulaması müslüman-zimmî ayrımı yapılmaksızın İslâm ülkesinde yaşayan herkes açısından söz konusudur. Bilindiği gibi zimmîler İslâm devleti hükümdarı veya onun yetki verdiği kişiyle zimmet bağıtı yaparak İslâm devleti vatandaşı haline gelen ehl-i kitap gayrimüslimlerdir. Bunlar Özel Hukuk ile ilgili konularda kendi cemaatlerinin koyduğu kurallara, Kamu Hukuku (ve tabii ki Ceza Hukuku) konularında ise İslâm Hukuku'nun kendileri için öngördügü kurallara tâbidirler ${ }^{5}$. Şu durumda, "Kasame" müessesesi de Ukubat içinde yer aldığına göre bu müessese ile ilgili düzenlemeler zimmîler için de geçerli olacak, yani bir zimmî faili meçhul bir cinayete kurban giderse, onun diyeti Kasame gereği, cesedin bulunduğu yer sakinlerince ödenecektir. Tüm İslâm devletlerinde olduğu gibi Osmanlı Devleti'nde de uygulama bu şekilde olmuştur.

2 Cin, Halil-Akgündüz, Ahmet: Türk Hukuk Tarihi, C. I, Kamu Hukuku, Konya, 1989, s. 276 - Lippman, Matthew-Mc.Conville, Sean-Yerushalmi, Mordechai: Islamic Criminal Law and Procedure, New York-London, s. 72.

3 Üçok, Coşkun-Mumcu, Ahmet-Bozkurt, Gülnihal: Türk Hukuk Tarihi, Ankara, 1996, s. 78.

4 Cin-Akgündüz, a.g.e., s. 276.

5 Zimmîlerle ilgili ayrıntılı bilgi için bkz., Üçok-Mumcu-Bozkurt, a.g.e., s. 70-71, 179181. 


\section{CEZALARIN ŞAHSîLİĞí ILKESININ TARİHTEKİ YERİ VE BU İLKENIN İSTISNAÎ UYGULAMALARI}

\section{A. Genel Olarak}

"Kasame" müessesesi "Akile" müessesesi ile birlikte İslâm Hukuku'nda "Cezaların Şahsîliği" ilkesinin bir istisnasını oluşturmakta, bu suretle faili meçhul bir cinayet suçunda fiili işlemedikleri halde başka kimseler cezalandırılmaktadır. Aslında tarih içinde eski hukuk sistemleri incelendiğinde, tıpk1 bu müesseselerde olduğu gibi cezanın şahsîleştirilmemiş olduğu başka bazı uygulamalara daha rastlanmaktadır. Yine tarihte kimi toplumlarda kasame veya ona benzer bazı müesseselerin varlığına da tanık olunmaktadır.

Bu noktada, tarihî süreç içinde öncelikle "Cezaların Şahsîliği" ve onun istisnası olan "Cezaların Kolektifliği" ilkelerinin ortaya çıkış sebeplerinin incelenmesinde yarar vardır. Bunun yanında "Cezaların Şahsîliği”" ilkesinden ayrılan çeşitli uygulamalara tarihteki değişik toplumlardan örnekler sunmak ve İslâm Hukuku'nu uygulamayan kimi hukuk sistemlerinin "Kasame" müessesesini ele alış biçimlerine yer vermek de gerekmektedir.

Bilindiği gibi, Batı'da "suç" ve onun karşıllğı olan "ceza" kavramları ancak XVII. yüzyıldan itibaren derinlemesine incelenen konular olmuşlardır. $\mathrm{Bu}$ sebeple, o tarihe kadar Ceza Hukuku'nun bugünkü modern anlayıştan bir hayli uzak kaldığı görülmektedir ${ }^{6}$.

Herşeyden önce şu belirtilmelidir ki, İlkel Ceza Hukuku Dönemi'nde zarar verici fiil veya hareketin aynı toplum içinde ve o toplumun bireylerine karşı işlenmesi durumunda Hâkim-Başkan suçluyu cezalandırmaktaydı. Bu cezalandırma faaliyeti aslında bir hukukî düzene bağlı değildi; doğal olarak suçta ve cezada kanunîlik prensibinden de söz etmeye imkân yoktu. Cezalandırılması gereken fiillerin ve bunlara karşı uygulanacak müeyyidelerin tayini Hâkim-Başkan'ın keyfî takdirine kalıyordu. Şu halde, sözü edilen dönemde zarar verici fiil aynı toplum içinde işlendiği zaman, cezalandırma bakımından bir güçlük ortaya çıkmıyordu; zira ceza vermeyi sağlayan ortak ve herkesin tâbi olduğu bir egemenlik gücü (Başkan'ın iktidarı) söz konusuydu. Bu uygulamada cezaların şahsîliğinden söz edilebilir?

Zarar verici fiilin iki ayrı toplumun fertleri arasında işlenmesi durumunda ise, bu toplumların üzerinde üstün ve ortak bir egemen güç bulunmadığ 1 için failin cezalandırılması imkânsızlaşmaktaydı. Bu durum "Öç Alma" denilen uygulamayı ortaya çıkarmış, böylece zarar verici fiil

Üçok-Mumcu-Bozkurt, a.g.e., s. 74.

Konuyla ilgili ayrıntılı bilgi için bkz., Dönmezer, Sulhi-Erman, Sahir: Nazarî ve Tatbikî Ceza Hukuku, C. I, İstanbul, 1987, s. 38, 39. 
veya harekete karşı bir tepki doğmuştur. Böyle bir sistem içinde sorumluluğun kişisel değil, kolektif olduğu görülmektedir; zira failin zarar verici davranışından onun mensup bulunduğu toplum bütünüyle bir karşılık görmektedir. "Öç Alma” uygulamasını o günün koşullarına göre olağan karşılamak gerekir; çünkü bu dönemde suçluyu yargılayacak ve cezalandıracak toplumlar üstü bir organ bulunmamaktadır. Ayrıca ailenin bireyleri arasında çok sıkı bir bağl1lık söz konusudur; üstün maddî ve manevî değerler ortak olup, mülkiyet de kolektiftir. Hal böyle olunca, suç teşkil eden fiil işlendiğinde öç alma failin mensubu bulunduğu topluma yöneltilmiş ve cezalandırmayı kolektif kılmıştır ${ }^{8}$.

Öte yandan "Öç Alma" toplumun kendini savunma hakkına bir dayanak olarak da görülmüş, zira mensuplarını koruyamayan bir toplumun sonunda zayıflayacağı, hatta bir gün ortadan kalkacağı düşünülmüştür. Bu sebeple öç alma hakkının kullanılması savaş hali bile sayılmış, bireylerin savaşa katılmalarını sağlamak için çeşitli ruhî ve sosyal saikler ortaya atılmıştır. Bu saiklerin etkisi altında öç alma yükümünü yerine getirmekten hiç kimse çekinemez, gerekli fedakârlıklara da seve seve katlanırdı. Şu halde öç alma sadece bir hak değil, aynı zamanda yerine getirilmesi zorunlu bir görev olarak kabul edilmiştir. ${ }^{9}$

Görüldügü gibi, cezanın kolektif olarak uygulanması tarihte ilk kez suç teşkil eden fiilin başka bir topluma veya onun bireylerine zarar vermesi durumunda ortaya çıkmıştır. Dikkat edilirse, bu aşamada devletin henüz tekel olarak ceza verme hakkı söz konusu değildir. Devlet bir süre sonra ceza verme yetkisine tek başına sahip hale geldiğinde, cezaların çoğunluğu için cezaların şahsîliği ilkesi geçerli olurken, bir kısım suçlarda da kolektif olarak cezalandırma yoluna gidilmiştir. $\mathrm{Bu}$, bir toplumda o günkü ihtiyaç ve şartlara göre yapılan bir tercih olarak algılanmalıdır.

Aynı durum İslâm Ceza Hukuku'nun uygulamaları olan "Akile" ve "Kasame" müesseselerinde de söz konusudur. İslâm Hukuk Sistemi günlük yaşamın bir ihtiyacı, bir gereği olarak aslında temel olarak benimsediği "Cezaların Şahsîliği" ilkesinden ayrılmak durumunda kalmış ve bu iki uygulamayı sürdürmüştür.

\section{B. Eski Uygarlıklarda Cezaların Şahsîliği İlkesine İstisna Teşkil Eden Uygulamalar}

Sadece İslâm Hukuk Sistemi'nde değil, aynı zamanda tarihteki değişik devletlerin hukuk sistemlerinde de günlük ihtiyaçların bir gereği olarak "Cezaların Şahsîliği”" uygulamasının çeşitli istisnaları ortaya çıkmıştır. Tarihî

\footnotetext{
8 Dönmezer, Sulhi: Cezaî Mesuliyetin Esası, İstanbul, 1949, s. 8 vd.

9 Dönmezer-Erman, a.g.e., s. 39-41.
} 
kaynak ve belgelerden öğrenilebildiği kadarıla tarihte yaşamış farklı devletlerin hukuk sistemlerindeki şu ilginç örnekler dikkat çekicidir:

Babiller'de, Hammurabi Kanunu'nun 23. maddesi bir hırsızlık olayında, hırsızın belli olmadığı veya yakalanamadığı durumlarda malı çalınan kimsenin, nesi çalındıysa bunu Tanrı huzurunda açıklamasını öngörmüş, topraklarında hırsızlık yapılan şehrin ileri gelenlerinin de çalınanları bu kişiye ödemesini hükme bağlamıştır ${ }^{10}$. Sözü edilen madde hükmü bir yandan cezaların şahsîliği ilkesinin bir istisnasını teşkil etmekte, bir yandan da kasame uygulamasına benzer bir sosyal dayanışma ve kontrol mekanizmasını ortaya koymaktadır. Ancak dikkat edilirse, bu maddede kasamedeki "cinayet" fiilinin yerini "hırsızlık" suçu almıştır.

Hititler'de bir hayvan kimin mülkünde öldürülmüşse o mülkün sahibi, sahipsiz arazide vuku bulan olaylarda veya failin bulunamadığ 1 durumlarda ise o yere en yakın yerleşim biriminde oturanlar bu tazminden sorumlu tutulmuşlardır $^{11}$. Görüldüğü gibi, bu uygulamada da İslâm Kamu Hukuku'ndaki Kasame müessesesine benzer bir durum söz konusudur. Ancak İslâm Ceza Hukuku'nun hayvanatta kasameyi kabul etmediği bilinmektedir ${ }^{12}$.

İran Moğolları'nda muhafazasına dikkat edilmeyen bir deli tarafından verilen zararlar delinin akrabasına yükletilirdi ${ }^{13}$.

Eski Türkler'de de cezanın kişiselleşmediği kimi uygulamalara rastlanmaktadır. Örneğin, Çin kaynaklarından öğrenilebildiği kadarıyla Hunlar'da eşkiyalık yapanın ailesi devlet memurları tarafindan rehine olarak tutulurdu ${ }^{14}$.

Göktürkler'de ise bir kimsenin gözünü kör eden kişi, kızını veya karısının mallarını o adama vermek mecburiyetindeydi ${ }^{15}$. Benzer şekilde, mahalle sakinlerinden birinin malı çalınırsa, diğer sakinler tazminle mükellef tutulurlard $1^{16}$.

Eski Türkler'e akraba olan ve hukuk sistemleri onlarla büyük ölçüde benzeşen Moğollar'da da cezaların şahsîleşmediği çeşitli uygulamalara

10 Tosun, Mebrure-Yalvaç, Kadriye: Sümer, Babil, Assur Kanunları ve Ammi-Şaduqa Ferman1, Ankara, 1989, s. 187. - Akdemir, Süleyman: Ceza Hukuku'nda Mağdurun Korunmas1, İzmir, 1988, s. 37, 38.

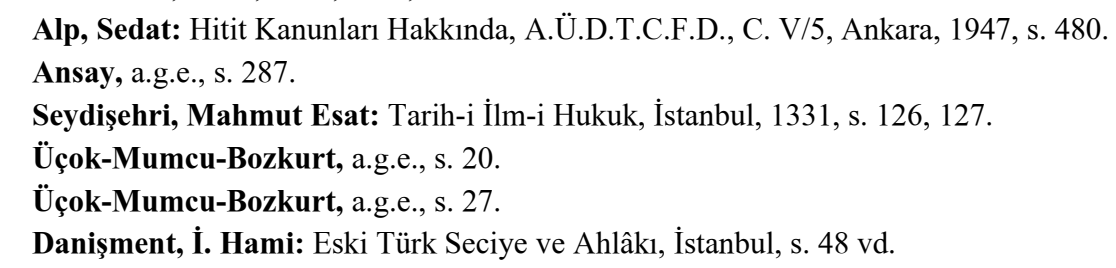


rastlanılmaktadır. Cengiz Han'ın ünlü yasasında yer alan ve konuyla ilgili bazı maddeler örnek olarak aşağıda gösterilmiştir:

Yasa'nın 29. maddesine göre, yanında çalınmış bir at bulunan bir kimsenin onu (atı) sahibine aynı değerde dokuz atla birlikte geri vermesi öngörülmüş, eğer buna malî gücü yetmiyorsa atların yerine çocuklarının alınması hükme bağlanmıştır. Eğer o kimsenin çocukları da yoksa, kendisi bir koyun gibi kesilecektir ${ }^{17}$. Bu madde ve Cengiz Han'ın Kanunnamesi'ndeki hırsızlığa ilişkin diğer maddeler yakından incelendiğinde, Moğol Hukuku'nda hırsızlık suçuna çok ağır cezaların öngörülmüş olduğu anlaşılmaktadır. 29. maddedeki “....atların yerine çocukların alınması" kuralı, hırsızlık fiiline verilen cezanın tam olarak şahsîleşmediğini ortaya koymaktadır. Burada çocukların bir köle olarak alındıkları ve iş gücü olarak kullanılacakları kuvvete muhtemeldir.

Öte yandan, Cengiz Han Yasası'nın "Hayata Karşı İşlenen Suçlar" başlığını taşıyan 6. Bölümü'nde, 2. maddede yer alan "Ayıkken başkasını öldüren kimsenin karısı, zırh ve silâhları ve varı yoğu alınmalıdır; tazminat ödeyecek kadar malı yoksa, öldürülenin hısımları katilin ileride elde edeceği malları, hatta mirasçılarının malları üzerinde nasafetli bir tazminat ödeninceye kadar hak iddia ederler"18 hükmünde de cezaların şahsîliği ilkesine bir istisna getirilmiştir. Dikkat edilirse, Moğol Hukuku'nda insan hayatına büyük değer verilmiş, öldüren kişinin en önemli mallarının, bu arada karısının elinden alınması öngörülmüştür. Göçebe bir toplum olan Moğollar'da diğer eski Orta Asya Türk devletlerinde (örneğin Hunlar, Göktürkler, Uygurlar) olduğu gibi göçebe yaşam tarzının getirdiği temel özellikler dikkat çekmektedir. Örneğin, eli silah tutanların tutmayanlara göre üstün sayılmaları, savaşkanlık, oldukça dinamik, disiplinli ve süratli bir yaşam biçiminin topluma egemen olması gibi ${ }^{19}$. Şu durumda savaşçı olarak bir erkeğin en önemli malları kuşkusuz atı ve silâhlarıdır. İşte, anılan maddede adam öldüren bir kimsenin bu tür mallarına el konulmakla suçlu adeta toplumdan dişlanmış olmakta, ayrıca karısı da elinden alınmakla bu kişi (karısı) açısından cezaların şahsîliği ilkesinden uzaklaşılmaktadır. Bu arada ölenin mirasçılarının katilin ileride elde edeceği malları ve onun mirasçılarının malları üzerinde yeterli bir tazminat alınıncaya kadar hak iddia edebilmeleri hükmü de cezaların şahsîliği ilkesinin Moğol Hukuku'nda

\footnotetext{
Alinge, Curt (Çev.: Coşkun Üçok): Moğol Kanunları, Ankara, 1967, s. 145.

Alinge, a.g.e., s. 157.

Göçebe Türk toplumlarının hukukî yapıları ve temel özellikleri ile ilgili ayrıntılı bilgi için bkz., Üçok-Mumcu-Bozkurt, a.g.e., s. 15-17. - Ögel, Bahaeddin: Türk Kültürünün Gelişme Çağları, C. II, İstanbul, 1971, s. 15 vd. - Claessen, Henri J.M.-Skalnik, Peter: Erken Devlet, Kuramlar-Veriler-Yorumlar, Çev.: Alâeddin ŞENEL, Ankara, 1993, s. 140-141.
} 
tam olarak yerleşemediğini göstermektedir. Ancak bu hükümlerin, bir taraftan da adam öldürme fiilinden zarar gören yanın zararının tam olarak karşılanmasına zemin hazırladığı söylenebilir.

Verilen örnekler daha da artırılabilir. Dikkat edilirse, tarihte yaşamış çeşitli toplumlarda cezanın suçu işleyene değil de başka kişilere uygulanması türlü biçimlerde, ama hep zararın tazmini amacıyla karşımıza çıkmaktadır. $\mathrm{Bu}$ uygulamalarda toplumların o günkü ihtiyaçları ve kanun koyucunun belirleyici rolü ön plâna çıkmaktadır.

\section{Tarihte Değişik Toplumlarda Kasame Uygulamaları}

Kasame İslâm orijinli olmayan bir kurumdur. Bu kurum başka kültür çevrelerinde de uygulama alanı bulmuştur.

Örneğin Hititler'de bir cinayet vukuunda, kişi kimin mülkünde öldürülmüşse o mülkün sahibi; sahipsiz arazilerde meydana gelen cinayetlerde veya failin bulunamadığı durumlarda ise, o yere en yakın yerleşim yerinde oturanlar tazminle sorumlu tutulmuşlardır ${ }^{20}$.

İran Moğolları'nda da bir arazide şüpheli bir ölüm ile bir ceset bulunduğunda, kasaba ahalisine katil diyetinin ödettirildiği anlaşılmaktadır ${ }^{21}$.

Cengiz Han'ın Kanunnamesi'nde ise, "Hayata Karşı İşlenen Suçlar"ın düzenlendiği 6. Bölüm, 16. maddede yer alan şu hüküm Moğollar'da "Kasame" uygulamasının bulunduğunu kanıtlamaktadır: "Meskûn bir yerde bir kimse öldürülmüş olarak bulunursa veya böyle bir yerde bir kimse bir çukura düşerek ölürse, buranın sâkinleri ölenin varislerine bir at ve dokuz hayvan tazminat olarak vermek mecburiyetindedir. O çevrede insan yok da yalnız yayılan hayvanlar varsa, ölenin hısımları tazminat olarak bu hayvanlardan alabilirler ${ }^{22}$.

Kasame uygulamasına eski Yunan'da, Yahudilik'te, Cahiliye Çağı Arapları'nda, hatta Ortaçağ İngilteresi'nde de rastlanmaktadır. Feodal sistemin geçerli olduğu Ortaçağ İngilteresi'nde, bir lordun malikânesi sınırları içinde katledildiği anlaşılan bir kişinin cesedi ele geçtiği zaman, lord ya beş gün içinde suçluyu yakalayıp diyet (kan bedeli) denilen bir tazminat almak zorundaydı, ya da katili bu süre zarfinda yakalayamazsa veya ceset ev, mahkeme binası gibi kapalı bir alanda bulunmuşsa, tazminatı kendisi ödemek durumundaydı. Ancak ceset açık bir alanda bulunmuşsa, malikâne halkı tazminatı aralarında eşit biçimde paylaşarak öderlerdi ${ }^{23}$.

\footnotetext{
Alp, a.g.m., s. 480.

Seydişehri, a.g.e., s. 126, 127.

Alinge, a.g.e., s. 158.

3 Painter, Sidney: Studies in the History of the English Feodal Barony, Baltimore, 1943, s. $80-82$.
} 
Görüldüğü üzere toplumsal ihtiyaçlar, tarihin çeşitli dönemlerinde Doğu-Batı ayrımı yapılmaksızın çok değişik toplumlarda benzer hukukî uygulamaları doğurmuştur. Bu da toplumların hukuk açısından birbirleriyle sürekli etkileşim içerisinde bulunduklarını ve benzer ihtiyaçların aynı hukuk düzenlemelerine yol açtığını bize göstermektedir.

\section{3. İSLÂM CEZA HUKUKU'NUN TEMEL ILKELERINDEN BİRI OLAN "CEZALARIN ŞAHSÎLİĞì" İLKESİ ve BU İLKENİN İKI İSTISNAÎ UYGULAMASI}

İslâm Ceza Hukuku'nda "Cezaların Şahsîliği”" ilkesi esastır. Nitekim Kuran'ın Enam Suresi'nin 164., İsrâ Suresi'nin 15., Fâtır Suresi'nin 18., Zümer Suresi'nin 7. ve Necm Suresi'nin de 38. ayetleri ile bir kimsenin, babasının ve kardeşinin suçlarından dolayı sorumlu tutulamayacağı hükme bağlanmıştır. Keza "Kuşkusuz suçlu sadece kendi aleyhine suç işler, yani işlediği suçundan sadece kendisi sorumludur" hadisiyle de cezaların şahsîliği ilkesi vurgulanmıştır ${ }^{24}$.

Ancak İslâm Ceza Hukuku'nun bu genel prensibinin dışında kalmış görünen iki müessese vardır ki, bunlar "Akile" ve "Kasame" müesseseleridir.

"Akile" failin yakın akrabaları olup, kasta benzer ve hataen adam öldürme suçlarında ve müessir fiillerde diyetin ödenmesinde faile yardımc1 olan kişilerdir. Diyetin akileye ödettirilmesi ilk bakışta "Başkasının Fiilinden Sorumluluk" olarak görülse de, cürmî kastı olmayan failin yükünü hafifletme amacına yönelik bir sosyal dayanışma müessesesi olarak da kabul edilebilir ${ }^{25}$. Ayrıca akilenin bu şekilde diyetin ödenmesine katılması bir sosyal kontrol mekanizması oluşturulması açısından suçları önleyici bir rol de oynamaktadir ${ }^{26}$.

Değişik İslâm mezheplerine göre kişinin akilesinin kimlerden ibaret bulunduğu tartışmalıdır. Ancak genelde kabul edildiği üzere failin yakın hısımlarının bulunmaması durumunda, yerine göre meslektaşları veya bir asker için onun mensup bulunduğu askerî birlik, yahut bir kasaba, bir aşiret, hatta Devlet Hazinesi bile "Akile" fonksiyonunu üstlenebilmektedir ${ }^{27}$.

İslâm Hukuku'nda cezaların şahsîliği prensibinin bir diğer istisnası da "Kasame" müessesesidir. Kasame, yukarıda tanımı yapıldığı üzere katili bulunmayan bir adam öldürme halinde, cesedin bulunduğu yer halkının bu ölünün diyetinden sorumlu tutulmasıdır. $\mathrm{Bu}$ durumda ölenin mirasçıları

24 Ramadan, Said: Islamic Law, Its Scope and Equity, Great Britain, 1961, s. 55.

25 Dağcı, Şamil: İslâm Ceza Hukuku’nda Şahıslara Karşı Müessir Fiiller, Ankara, 1999, s.35.

26 Aydın, M. Akif: Türk Hukuk Tarihi, İstanbul, 1999, s. 182.

27 Cin-Akgündüz, a.g.e., s. 273. 
civarda oturan elli kişiyi seçmekte ve bu kişiler katilin kendileri olmadığ 1 hususunda yemine davet edilmektedirler. Bu elli kişi katil olmadıkları ve katili de bilmediklerine dair yemin edince, ölünün diyeti o kasaba halkı arasında eşit olarak paylaştırılmaktadır. Böylece bölgedeki halkın kendi çevrelerindeki asayiş ve düzeni yürütmeleri sağlanmak istenmektedir. Bunun içindir ki, diyete hükmedilebilmesi için cesedin bulunduğu yerden bağırıldığında o kasabada oturanların bu sesi duyabilmeleri şartı esas alınmaktadır ${ }^{28}$.

Konuyla ilgili olarak ünlü Osmanlı Şeyhülislâmı Ebussuud Efendi'nin iki fetvası aşağıya alınmıştır. $\mathrm{Bu}$ fetvalardan anlaşılabildiği kadarıyla, cesedin bulunduğu yerden bağırıldığında o kasabada oturanlar bu sesi duyabilecek durumdalarsa, o yer sakinlerinin diyet yükümlülükleri doğmaktadır.

\section{FETVA-I}

Mesele : Zeyd bir mağaranın içinde mecruhen maktul bulunup, mağaranın üzerinden şiddetle nidâ olundukta karyeye avaz işitilir yerde olsa, mezbûre karye ahalisine diyet lâzım olur mu?

El Cevap : Olur $^{29}$.

\section{FETVA-II}

Mesele : Bir kasaba kurbunda Zeyd maktul bulunup, katili malum olmayıp, avaz cümle kasabaya işitilir olsa. Diyeti cümle kasaba ahalisine mi lâzım olur, yoksa ol tarafta olan mahalle ehline mi?

El Cevap : Kurbunun ehline lâzım olur ${ }^{30}$.

Ceset daha uzak bir yerde bulunduğunda ise, kasaba halkının elbette bu yerdeki asayiş ve düzeni sağlamakla yükümlü olamayacağı kabul edilir ve diyet borcu söz konusu olmaz ${ }^{31}$.

Görüldüğü gibi "Akile" ve "Kasame" müesseseleri İslâm Ceza Hukuku'nda kolektif ceza sorumluluğunun dikkat çekici iki örneğini oluşturmaktadırlar. $\mathrm{Bu}$ müesseseler "Cezaların Şahsîliği" ilkesinin Ukubat'taki iki istisnasıdır.

4. KASAME UYGULAMASINDA CEZALANDIRMAYA ETKI EDEN “CEZALARIN DINÎLIĞİ” İLKESİ

"Kasame" müessesesinin uygulanmasinda İslâm Ceza Hukuku'nun temel ilkelerinden biri olan "Cezaların Dinîliğì" ilkesinin özel bir yeri

\footnotetext{
Dönmezer-Erman, a.g.e., s. 109.

29 Düzdă̆, M. Ertuğrul: Şeyhülislâm Ebussuud Efendi Fetvaları, İstanbul, 1983, s. 155, 156.

30 Düzdağ, a.g.e., s. 156.

31 Dönmezer-Erman, a.g.e., s. 109.
} 
bulunmaktadır. Nitekim bu ilkeye göre, İslâm'daki cezaî hükümler aynı zamanda birer dinî yasak veya emir olarak düşünüldükleri için, bu hükümlere dünyadaki itaat veya itaatsizlik, ahirette karşılaşılacak mükâfat veya cezayı insanlara düşündürür ve müslümanları bu hükümlere uymaya teşvik eder. Buna göre, örneğin ispat edilemediği için dünyada cezasız kalan bir fiilden dolayı ahirette mutlaka bir hesaba çekilme ve cezalandırılma olacağını düşünen bir Müslüman için ahiret inancı ve bunun içerdiği uhrevî tehdit, mutlaka bir genel önleme ve faili meçhul cinayetlerde suçluların ortaya çıkmasında önemli bir psikolojik faktör olacaktır. İşte bu inanç, polis takibi olmadan da bazı suç faillerinin bizzat adalete başvurarak suçlarını ikrar ve itiraf etmelerine vesile teşkil edecektir ${ }^{32}$.

"Cezaların Dinîliği” ilkesi bu özelliğiyle suçlarla ilgili sosyal kontrol ve savunma mekanizmasının etkinliğini de sağlamayı hedeflemektedir. Bu çerçevede dinî vecibeler İslâm toplumunda, suç teşkil edecek bir fiilin hiç işlenmemesini sağlamak üzere insanların birbirlerini sürekli kontrol altında tutacakları bir ortamı yaratma amacını taşımaktadır ${ }^{33}$.

Söz konusu amaç "Kasame" suçlarında belirgin bir şekilde göze çarpmaktadır. Şöyle ki, faili meçhul bir cinayet vukuunda o mahalde yaşayan insanlar, aralarında her zaman bulunması gereken sosyal kontrolü sağlayamadıkları ve suçun işlenmesine engel olamadıkları için cezalandırılmaktadırlar. Halbuki bu kişiler suç teşkil eden fiil gerçekleşmeden önce gerekli kontrol ve dayanışmayı aralarında sağlayabilselerdi, hem suç ortaya çıkmayacak, hem de kendilerinin cezalandırılmasına mahal verecek bir ortam doğmayacaktı. Şu halde Kasame suçlarında, suçu doğrudan işleyen kişiler durumunda olmadıkları halde, fiilin vuku bulduğu mahalde yaşayan ahalinin cezalandırılma sebebi İslâm Hukuku'nun getirdiği "Cezaların Dinîliği" ilkesiyle net bir biçimde anlaş1labilmektedir.

Görüldüğü gibi, İslâm Hukuku suçları önlemede terbiye edilmiş genel bir kamuoyu meydana getirmeyi amaçlamaktadır. $\mathrm{Bu}$ sayede toplumda kötülüklerin hiç ortaya çıkmaması, hep iyiliklerin olması istenmiştir ${ }^{34}$. Nitekim Kuran'ın Âli İmran Suresi'nin 104. Ayeti'nde "Sizden iyiliğe çağıran, doğruluğu emreden ve fenalıktan meneden bir cemaat olsun. İşte başarıya erişenler yalnız onlardır" denilmek suretiyle bu gerçeğe işaret edilmiştir. İslâm Hukuku iyiliği emreder ve kötülükleri de yasaklarken, bunun suçların önlenmesinde işbirliği yapılmasıyla sağlanabileceğinin altını çizmektedir. İște Kasame uygulamasında toplum

Awwa, Muhammad Salim: The Basis of Islamic Penal Legislation, New York, s. 131.

Dağcı, a.g.e., s. 37, 38.

Ebu Zehra, Muhammad (Çev.: Hasan Güleç): İslâm Ceza Hukuku'nda Merhamet ve Adalet, D.E.Ü.İ.F.D., S. III, İzmir, 1986, s. 257. 
üyeleri, hem suçun önlenmesinde hem de cezalandırılmada kolektif bir sorumluluk altına girmektedirler.

Öte yandan İslâm Hukuku adam öldürme suçunu bütün insanlığa karş1 işlenmiş bir suç olarak görmek suretiyle insan hayatına verdiği önemi gözler önüne sermiştir. Kuran'da Mâide Suresi'nin 32. Ayeti'nde "Kim bir kimseyi, bir kimseye veya yeryüzünde bozgunculuğa karş1lık olmadan öldürürse, bütün insanları öldürmüş gibi olur. Kim de onu ölümden kurtarırsa bütün insanları diriltmiş gibi olur" hükmü yer almaktadır. Şu durumda İslâm Hukuku'nda insan hayatına verilen önem, mağdurun uğradığı zararın derhal ve tam olarak telâfi edilmesini gerektirmektedir. Bu da failin bilindiği durumlarda kısas ile mümkün olmakta, failin meçhul olduğu durumlarda ise, öldürülenin akilesinin mağduriyetinin giderilmesi esas alınmakta ve "Kasame" gereğince diyete hükmedilmektedir.

Fail meçhul olsa da, adam öldürme suçunda kısas veya diyete gidilmesi ${ }^{35}$ toplumu intikam duygusundan ve onun ileri derecede uygulamaları olan öç alma ve kan davasından uzaklaştırmayı hedeflemektedir. Çünkü kısas ve diyet sayesinde hem "Cezaların Dinîliği”" ilkesi gereği Tanrı'nın emrinin yerine getirilmesi dolayısıyla toplumda iç huzur sağlanmakta; böylece öç alma ve kan davasına gerek kalmamakta, hem de mağdurun yakınlarının gönlündeki intikam ateşi söndürülmektedir ${ }^{36}$.

Görüldüğü gibi， İslâm Hukuku'nda “Cezaların Dinîliği” ilkesi vasıtasıyla, işlenen hiçbir suçun cezasız bırakılmayacağı ve her halde mağduriyetin giderileceği kuralı konmuş olmaktadır.

\section{KASAME YEMINI}

Yukarıda da izah edildiği üzere bir köy, kasaba veya şehirde faili meçhul bir ölü bulunduğu takdirde, kasame gereği o yerin sakinlerinden elli kişiye "onu öldürmediklerine ve öldüreni de bilmediklerine" dair yemin ettirilmektedir.

Kendilerine yemin tevcih edilen kişilerin erkek olmaları gerekir; çünkü kadınların kısas ve hadd suçları ile ilgili davalarda kadılık yapabilmeleri ve tanık olabilmeleri mümkün görülmemiştir ${ }^{37}$. Kasame müessesesinde aslında kısası (cana karşı kısas) gerektiren bir durum söz konusudur. Ancak fail belli olmadığı için ceza diyete dönüşmektedir. Bu sebeple kasame diyet uygulamasının bir alt türü olarak düşünülmüş, kadınların kısas ve hadd suçlarıyla ilgili davalarda tanıklık yapamamaları kuralı kasame için de kabul edilmiştir.

\footnotetext{
35 "Kısas" ve "Diyet" müesseselerinin hukukî mahiyetleri ile ilgili ayrıntılı bilgi için bkz., Üçok-Mumcu-Bozkurt, a.g.e., s. 75 vd. - Cin-Akgündüz, a.g.e., s. 271 vd. - CinAkyılmaz, a.g.e., s. 232 vd. - Aydın, a.g.e., s. 202 vd.

36 Ebu Zehra, a.g.m., s. 258.

37 Üçok-Mumcu-Bozkurt, a.g.e., s. 82.
} 
Öte yandan, kadı huzuruna çıkan elli kişinin tanıklık için aranan diğer koşullara da sahip kişiler olmaları gerektiğinde bir kuşku yoktur. Dolayısıyla özgür, ergin, mümeyyiz, işittiğini anlar, istediğini söyleyebilir, adil ve zina iftirasından dolayı kazf haddi ile cezalandırılmamış, örf-adete ve sosyal düzeyine uygun olarak yaşamış ve tanıklığı ile bir çıkar sağlamak istememiş olmak koşullarını taşıyan erkekler kasame yemini etmeye ehil sayılmışlardır ${ }^{38}$.

Kasame yeminini etmek üzere o yerde yaşayan elli erkek bulunmazsa, bulunanlar yeminlerini elliye tamamlayacaklar, böylece eksiklik tamamlanıp yemin, usulüne uygun bir biçimde yerine getirilmiş olacaktır. Hz. Muhammed'in ve Hz. Ömer'in faili meçhul ölüm hadiselerinde, elli kişiye kasame yemini ettirdikleri çeşitli kaynaklardan öğrenilmektedir. Öte yandan, ünlü halifeler Ömer bin Abdülaziz ve Abdülmelik bin Mervan'ın da bu yoldaki uygulamalarına rastlanmaktadır ${ }^{39}$. Hz. Peygamber ve çeşitli halifelerin sözü edilen uygulamaları daha sonraki yüzyıllarda İslâm Hukuku uygulayıcılarına yön gösterici olmuştur.

\section{KASAME YEMININDEN KAÇINMA (NUKUL)}

"Kasame" yemininden kaçma söz konusu olduğunda, yeminden kaçmaya ilişkin genel hükümlerin uygulanması gündeme gelir. Davalının yeminden kaçınması (nukul) haliyle ilgili olarak İslâm tarihinde şu uygulamalarla karşılaşılmıştır: Örneğin Hz. Osman bir alışverişten ötürü çıkan davada, davalının yeminden kaçınması üzerine onun aleyhine hükmetmiş, Hz. Ömer de bir davada yeminden nukul durumunda benzer şekilde karar vermiştir. Ünlü Kûfe Kadısı Şureyh'in de yeminden nukul durumunda davalının aleyhine hükmettiği bilinmektedir. Bir başka ünlü kadı, Basra Kadısı İbn Ebi Müleyke de kendisine gelen bir davada zamanın serbest çalışan müftüsü İbn Abbas'tan davayı nasıl halledeceğini sorduğunda, O'ndan "Davacıdan delil getirmesini iste. Şayet davac1 delil getiremezse davalıya yemin teklif et. Davalı yeminden kaçınırsa, onun aleyhine hükmet" cevabını almıştır.

Hz. Ali'nin de yeminden kaçınma halinde benzer şekilde hareket ettiği bilinmektedir. Ancak Hz. Ali davalının yemin etmesini müteakip davacıya da yemin tevcih etme usulünü uygulamıştı ${ }^{40}$. Hz. Ali'nin bu uygulamasını mutlak hakikate ulaşma ve en doğru kararı verme yolunda bir girişim olarak değerlendirebilmek mümkündür.

38 İslâm Hukuku'nda tanıklık şartları ile ilgili ayrıntılı bilgi için bkz., Üçok-MumcuBozkurt, a.g.e., s. 83.

39 Konuyla ilgili ayrıntılı bilgi için bkz., Atar, Fahrettin: İslâm Adliye Teşkilâtı, Ankara, 1999, s. 212.

$40 \quad$ Atar, a.g.e., s. 211. 
Yeminden kaçınma durumunda, davanın davalının aleyhine sonuçlanması ile ilgili uygulamanın kasame müessesesinde pratik bir sonuç getirmeyeceği söylenebilir. Şöyle ki; bir yerde faili meçhul bir cinayet ile karşılaşıldığında, o yerdeki elli erkek usul gereği yemine davet edilmektedirler. Bu elli kişinin ettiği yemin aslında onların suçu işlediklerine dair bir karine teşkil etmektedir. Çünkü bu kişiler faili görmemekle ve suçun işlenmesine engel olmamakla o yerde huzurun teminini imkânsız kılmışlardır; şu halde cezalandırılacaklardır ${ }^{41}$. Dolayısıyla, Kasame'de yemine davet edilenlerin yeminden kaçmaları diye bir durum söz konusu olamaz. Öldürülen kişinin diyeti bu kişilerce ödenmek zorundadır. Yeminden kaçınma durumunda, kaçınan kimsenin yemin edene veya fiili ikrar edene kadar hapisle tazyik edilmesinin sebebi de budur.

Öte yandan şahadette bulunmak ve bu suretle suçların ispatını kolaylaştırmak İslâm Hukuku'nun temel olarak benimsediği adaletin de bir gereğidir. Bu sebeple suç teşkil eden bir fiili görenlerin bunu derhal devlet makamlarına bildirmeleri ve Kasame'de olduğu gibi bir davayı açıklığa kavuşturmak üzere çağrılanların da tanıklıkta bulunmaları bir zorunluluk arz etmektedir ${ }^{42}$. Bu konuda Nisâ Suresi'nin 135. Ayeti "Ey inananlar; kendiniz, ana-babanız ve yakınlarınız aleyhine de olsa şahit olarak adaleti gözetin; ister zengin olsun, ister fakir olsun Allah onlara daha yakındır. Adaletinizde heveslere uymayın. Eğer eğriltirseniz veya yüz çevirirseniz, bilin ki Allah işlediklerinizden şüphesiz haberdardır" hükmünü getirmiştir.

Şu halde, kasame yemininden kaçılmasının mümkün olmadığı sonucuna ulaşılabilir. İslâm Ceza Hukuku'nun adaletin temin edilmesi ve mağduriyetin giderilmesine yönelik temel amacı bu şekilde yerine getirilmiştir.

\section{KASAME MÜESSESESINIIN SUÇU ÖNLEMEDEKI}

\section{FONKSIYYONU}

İslâmiyet, daha önce Cahiliye Arapları'nda da var olan Kasame müessesesini ıslah ederek almış ve esas itibarıyla mağdurun korunması için bir yol olarak kabul etmiştir ${ }^{43}$. Faili meçhul bir cinayete kurban giden bir kişinin akilesinin mağdur durumda bırakılmaması ve suçun cezasız kalmaması açılarından kasame uygulaması dönemin ceza hukuku anlayışına uygun bulunmuştur. İslâm toplumunda yaşayan tüm insanlara, suç daha işlenmeden önce bulundukları yerin emniyetini sağlama ve sürdürme, ayrıca hakları tecavüze uğrayan kimselere de yardım etme yükümlülüğü

\footnotetext{
Üçok-Mumcu-Bozkurt, a.g.e., s. 78.

Ebu Zehra, a.g.m., s. 252 vd.

Ateş, A. Osman: İslâma Göre Cahiliye ve Ehl-i Kitap Örf ve Adetleri, İstanbul, 1996, s. $426 \mathrm{vd}$.
} 
getirilmektedir. Bir bölgede yaşayan insanlar gerek içlerinden, gerekse dışarıdan birtakım suça eğilimli ve kötüniyetli kimselerin çıkarak o bölgenin güvenliğini ihlâl etmesine izin vermemelidirler. Dolayısıyla, bir bölgede bir cinayetin meydana gelmesi o yer ahalisinin görevlerinde müsamaha gösterdikleri anlamına gelir; bu sebeple de haklarında bir tür ceza olarak "Kasame" ve "Diyet" icap eder ${ }^{44}$.

Görüldüğü gibi, kasame uygulaması sayesinde sosyal bir kontrol mekanizması oluşturulmak istenmiştir. Böylece toplum fertlerinin sürekli biçimde birbirlerini kontrol altında tutmaları ve toplumdaki suç yüzdesinin azaltılması amaçlanmıştır.

\section{KASAMEDE DIYYETIN ÖDENMESİ USULÜ}

Faili meçhul cinayetlerde özel bir yemin usulüyle ölenin diyetinin ödettirilmesi anlamına gelen Kasame'de diyetin nasıl, kimler tarafindan ve kimlere ödeneceği konusunda değişik olasılıklar ortaya çıkmakta ve buna göre uygulama da değişmektedir.

Her şeyden önce şu ifade edilmelidir ki; Kasame uygulaması için maktul yakınlarının şikâyette bulunmaları veya dava açmaları gerekir ${ }^{45}$. Ancak maktul yakınlarının tespit edilememesi durumunda veya şikâyette bulunabilecek bir yakını olmayan birisi cinayete kurban gittiğinde, devlet organlarının resen harekete geçme yükümlülüğü doğmaktadır. Hz. Ömer'in öldürülüp yol kenarına atılan bir gencin katilini bulmak için bir yıl kadar süren bir tahkikat yaptırdığı bilinmektedir. Böyle bir durumda Kasame gereği ödenmesi gereken diyet bedeli, şayet cinayet özel bir arazide işlenmişse arazinin maliki tarafından Devlet Hazinesi'ne (Beytülmal'e) ödenecek, şayet ölünün bulunduğu yer kamuya ait bir arazi ise Devlet'in hem diyet alacağı, hem de diyet borcu söz konusu olacağı için herhangi bir ödemeye gerek kalmayacaktır.

Buna karşılık maktulün yakınları var ve bunlar belli ise; ölünün bulunduğu yerin mülkiyeti özel kişilere veya bir köyün tüzel kişiliğine aitse diyet onlar tarafindan, kamuya aitse Devlet tarafindan maktul yakınlarına ödenecektir ${ }^{46}$.

Şayet bir misafir bir kimsenin evindeyken öldürülür ve katil tespit edilemezse, diyet Ebu Hanife'ye göre mülk sahibinden alınır. Ama İmameyn ${ }^{47}$ e göre diyet bu durumda o mülkte fiilen ikamet etmekte olan

Atar, a.g.e., s. 212.

Avcı, Mustafa: Osmanlı Hukuku'nda Suçlar ve Cezalar, İstanbul, 2004, s. 82.

Bilmen, Ö. Nasuhi: Hukuk-i İslâmiyye ve Istılâhât-1 F1khiyye Kamusu, C. III, İstanbul, 1975 , s. 160.

47 “İmameyn", Hanefîlik Mezhebi'nin Kurucusu Ebu Hanife'nin iki öğrencisine verilen isimdir. Ebu Yusuf ve İmam Muhammed kimi zaman hocaları Ebu Hanife'ye zit olan görüşleriyle ön plana çıkmışlar ve Mezheb'in gelişmesine büyük katkı sağlamışlardır. Bu sebeple İmameyn Ebu Hanife ile birlikte Hanefîlik Mezhebi'nin kurucusu sayılır. Konuyla ilgili ayrıntılı bilgi için bkz., Üçok-Mumcu-Bozkurt, a.g.e., s. 62. 
kişiden alınmalıdır. Osmanlı uygulamasında da, Ebussuud Efendi'nin bir fetvası gereği İmameyn'in içtihadı tercih edilmiştir. Konuyla ilgili ünlü Osmanlı Şeyhülislâmı'nın fetvası aşağıda verilmiştir:

Mesele: "Taife-i kefere icâre ile tasarruf ettikleri meyhanelerde katil vâki olup, katil bilinmeyecek" ve "sancak beyi, subaşıları zencir ile mahbus ile bir karyeye gelip, cebr ile bir evde konup, sahibini çıkarıp, gece ile mahbusların bazı ol evde maslûb yahut maktul bulunup, eden malum olmayacak, diyet kime düşer?” deyu çok istifsar olunur. Bunun gibilerde İmam-1 Â'zam katında "ol mevzi mühlik ise diyet malikine düşer, vakıf ise vakıf canibine düşer". İmam Ebu Yusuf katında "tasarruf edene düşer, hatta konuk konduğu evde maktul bulunup, katil bilinmeyecek, ev müstakillen konuk elinde olup sahibi bile sakin olmayacak, sahibine diyet ve kasame lâzım olmaz". Bu makûlelerde mülk sahibinin ve vakıf cânibinin alâkası olmayıp âhar yerde, lâkin diyet onlara tahmil olunup, İmam-1 Â'zam kavli ile amel olunup, mutasarrıf olanların hıfzında taksîrât ve müsâhelelerine mü'eddî olup, İmam Ebu Yusuf kavli ile amel olunup diyet mutasarrıf olanlara tahmil olunmak hıfzda ve hirâsette ziyade ihtimamlarına bâis, def-i fesâda enseb görülüp, atebe-1 'ulyâya arz kılındı.

El cevap: Bu hususta "Hazret-i İmam Ebu Yusuf kavli ile amel oluna" deyu ferman olundu ${ }^{48}$.

Kasamede failin daha sonradan bulunması durumunda devlet başkanının bu kimseyi affetme yetkisi İslâm Hukuku'nca kabul edilmemiştir. Üstelik devlet başkanının kasame gereği daha önceden Beytülmal'ce ödenen diyeti Beytülmal adına bu kimseden (failden) tahsil etmesi gerekir. Hatta Malikîler'e göre sonradan bulunan fail kısasa da uyruk tutulmalıdır ${ }^{49}$.

\section{SONUC}

İslâm Ceza Hukuku'nda, tüm modern hukuk sistemlerinde de kabul edildiği gibi "Cezaların Şahsîliği" ilkesi esastır. Ancak toplumsal yaşayışın getirdiği çeşitli ihtiyaçlar karşısında İslâm Hukuku'nda bu ilkeden bazı sapmalar kabul edilmiştir. "Akile" ve Kasame" kavramları "Cezaların Şahsîliği”" ilkesinin İslâm Hukuku'ndaki istisnaî uygulamalarıdır.

İslâm Hukuku Cahiliye Çağı'ndan henüz kurtulmuş Arap toplumuna getirdiği pek çok ileri ilkeyle adeta bir devrim yaratmıştır. İslâm öncesi Cahiliye Çağı'nda da uygulanan bazı hukukî müesseseler İslâm Hukuku'nca 1slah edilerek kabul edilmiş, Arap toplumu nicedir hasret kaldığı dirlik ve düzene bu suretle kavuşabilmiştir. İslâmlık ilke olarak toplumsal barışı esas alan bir kurallar bütünü olduğu için bu temel ilkeyi sağlama yolunda çeşitli düzenlemeler getirmiştir. İşte bu düzenlemelerden birisi olan "Kasame" her

\footnotetext{
48 Düzdăg, a.g.e., s. 156.

49 Avcı, a.g.e., s. 82.
} 
ne kadar bir başka temel İslâm ilkesi olan "Cezaların Şahsîliğị" ilkesiyle çelişse de, İslâm toplumunda uygulama alanı bulmuştur.

Kasame gereğince, bir yerde faili meçhul bir cinayet vuku bulduğunda, o yerde yaşayan elli erkeğin bu cinayeti işlemedikleri ve faili de bilmediklerine dair ettikleri yemin, aslında bu suçu o yer ahalisinin işlediğine bir karine sayılmakta ve onlar mağdurun akilesine diyet ödemekle yükümlü kılınmaktadırlar. Çünkü, aslında suçu işlemedikleri halde tazmin ile yükümlü kılınan kişiler, bulundukları mahalde suçun ortaya çıkmasına engel olmamakla ve faili görmemekle oranın huzurunu kaçırmış sayılmaktadırlar. Görüldüğü gibi kasame müessesesi, bir mahalde yaşayan insanlar arasında sosyal kontrol mekanizmasının sağlanmasını öngörmektedir. Burada bütün insanların birbirlerini sürekli kontrol ederek ve aralarında dayanışma sağlayarak o mahalde bir suçun işlenmesine engel olmaları arzulanmaktadır. Kasame uygulamasıyla, işlenen suç cezasız bırakılmamakta, ayrıca suçtan zarar gören kişinin yakınları failin bilinmemesi sebebiyle mağdur edilmemekte ve zararlarının tazmini yoluna gidilmektedir.

Aslında bir sosyal dayanışma ürünü ve göstergesi olan Kasame müessesesi o günkü şartlara göre olağan karşılansa da, bugünkü modern ceza hukuku anlayışı ve insan hakları açısından bu cezanın savunulabilecek bir yönü kalmamıştır. 


\section{KAYNAKÇA}

AKDEMIR, Süleyman: Ceza Hukuku'nda Mağdurun Korunması, İzmir, 1988.

ALINGE, Curt (Çev.: Coşkun ÜÇOK): Moğol Kanunları, Ankara, 1967.

ALP, Sedat: Hitit Kanunları Hakkında, A.Ü.D.T.C.F.D., C. V/5, Ankara, 1947, s. 465-482.

ANSAY, Sabri Şakir: Hukuk Tarihinde İslâm Hukuku, Ankara, 1958.

ATAR, Fahrettin: İslâm Adliye Teşkilâtı, Ankara, 1999.

ATEŞ, A. Osman: İslâma Göre Cahiliye ve Ehl-i Kitap Örf ve Adetleri, İstanbul, 1996.

AVCI, Mustafa: Osmanlı Hukuku'nda Suçlar ve Cezalar, İstanbul, 2004.

AWWA, Muhammad Salim: The Basis of Islamic Penal Legistation, New York.

AYDIN, M. Akif: Türk Hukuk Tarihi, İstanbul, 1999.

BİLMEN, Ö. Nasuhi: Hukuk-i İslâmiyye ve Istılâhât-1 Fıkkiyye Kamusu, C. III, İstanbul, 1975.

CİN, Halil-AKGÜNDÜZ, Ahmet: Türk Hukuk Tarihi, C. I, Kamu Hukuku, Konya, 1989.

CIN, Halil-AKYILMAZ, Gül: Türk Hukuk Tarihi, Konya, 2003.

CLAESSEN, Henri J.M.-SKALNIK, Peter (Çev.: Alâeddin ŞENEL): Erken Devlet, Kurumlar - Veriler - Yorumlar, Ankara, 1993.

DAĞCI, Şamil: İslâm Ceza Hukuku'nda Şahıslara Karşı Müessir Fiiller, Ankara, 1999.

DANIŞMENT, İ. Hami: Eski Türk Seciye ve Ahlâkı, İstanbul.

DÖNMEZER, Sulhi: Cezaî Mesuliyetin Esası, İstanbul, 1949.

DÖNMEZER, Sulhi-ERMAN, Sahir: Nazarî ve Tatbikî Ceza Hukuku, C. I, İstanbul, 1987.

DÜZDAĞ, M. Ertuğrul: Şeyhülislâm Ebussuud Efendi Fetvaları, İstanbul, 1983.

EBU ZEHRA, Muhammad (Çev.: Hasan GÜLEÇ): İslâm Ceza Hukuku'nda Merhamet ve Adalet, D.E.Ü.İ.F.D., S. III, İzmir, 1986, s. 245-260.

LIPPMAN, Matthew-Mc.CONVILLE, Sean-YERUSHALMI, Mordechai: Islamic Criminal Law and Procedure, New York-London.

ÖGEL, Bahaeddin: Türk Kültürünün Gelişme Çağları, C. II, İstanbul, 1971.

PAINTER, Sidney: Studies in the History of the English Feodal Barony, Baltimore, 1943.

RAMADAN, Said: İslamic Law, Its Scope and Equity, Great Britain, 1961.

SEYDIŞEHRİ, Mahmut Esat: Tarih-i İlm-i Hukuk, İstanbul, 1331.

TOSUN, Mebrure-YALVAÇ, Kadriye: Sümer, Babil, Assur Kanunları ve Ammi Şaduqa Fermanı, Ankara, 1989.

ÜÇOK, Coşkun-MUMCU, Ahmet-BOZKURT, Gülnihal: Türk Hukuk Tarihi, Ankara, 1996. 